\begin{abstract}
Досліджено процес заповнення прес-форм для лиття під тиском полімерних виробів складної конфігурачії. Розроблено математичну модель динаміки руху в'язкої рідини з вільною поверхнею в оформлюючій порожнині прес-форми. Математичну модель побудовано на основі використання методу маркерів та комірок. Проведено експериментальні дослідження, що підтверджують аналітичні результати

Ключові слова: прес-форма, розплав полімеру, поле ивидкостей, поле тисків, розрахункова сітка, спаї
\end{abstract}

Исследован процесс заполнения прессформ для литья под давлением полимерных изделий сложной конфигурации. Разработана математическая модель динамики течения вязкой жидкости со свободной поверхностью в оформляющей полости пресс-формы. Математическая модель разработана на основе метода маркеров и ячеек. Проведены әкспериментальные исследования, подтверждающие аналитические результать

Ключевые слова: пресс-форма, расплав полимера, поле скоростей, поле давлений, расчетная сетка, спаи
口-
UDC 678.027 .74

DOI: $10.15587 / 1729-4061.2017 .110820$

\section{MODELING A PROCESS OF FILLING THE MOLD DURING INJECTION MOLDING OF POLYMERIC PARTS}

\author{
T. K u lik \\ $\mathrm{PhD}$, Associate Professor* \\ E-mail: t-81@ukr.net \\ O. S y n y u k \\ $\mathrm{PhD}$, Associate Professor \\ Department of Machinery and Apparatus \\ Khmelnytskyi National University \\ Instytutska str., 11, Khmelnytskyi, Ukraine, 29016 \\ E-mail: synoleg@ukr.net \\ B. Zlot e n k o \\ Doctor of Technical Sciences, \\ Professor, Head of Department* \\ E-mail: zlotenco@ukr.net \\ *Department of Electromechanical Systems \\ Kyiv National University of Technologies and Design \\ Nemirovycha-Danchenka str., 2, Kyiv, Ukraine, 01011
}

\section{Introduction}

Polymeric materials have become widespread in the manufacture of parts in different fields, including light industry. When producing shoes, polymerics are used for manufacturing soles, heels, heeltaps, sub-socks and buttresses, aggregated nodes, shoe pads, etc. Polymeric materials possess important advantages compared to traditional materials. First, raw materials have a relatively low cost and can be obtained in almost unlimited quantities. Second, polymeric materials are easily processed in different ways and demonstrate beneficial physical and mechanical characteristics. All this makes it possible to receive products with specific, preset in advance, properties. Polymeric materials have a wide range of physical properties, such as strength, rigidity, opacity, color, viscosity, hardness, ductility, heat resistance, thermal conductivity, electrical conductivity, etc. They can consequently be used in the manufacture of various goods. The properties of polymerics are so varied that they can serve substitutes both for metals and natural fibers, particularly silk and wool [1].

The most common technique for fabricating parts from polymeric materials is the injection molding [2]. At present, about a third of thermoplastics are processed in this way. Due to performance efficiency and manufacturability, injection molding is very effective for large volumes of production. Injection molding enables receiving parts of different shapes, with high precision and clean surface. Cast products require almost no finishing treatment that makes it possible to re- duce the amount of industrial waste and shorten duration of the production process.

Quality of the molded parts is a function of the type of material, technological parameters of the process of injection molding, the geometry of parts' surface and a mold design. Development and improvement of equipment and technologies for processing polymeric materials are considered as important as the invention of polymers itself [3].

Technological parameters of the injection molding process, namely, melt temperature, temperature of the mold, and injection molding pressure are determined by the type of material. A manufacturer of the raw materials typically recommends optimal values of the specified parameters that ensure high quality of the resulting product. The geometry of the product also exerts significant influence on the process of filling the mold. Formation of products with a complex geometrical shape predetermines a difficult relief of the mold cavities, which complicates filling the mold and uniformity in cooling a product. As a consequence, it is possible to receive flawed goods that may have the unformed elements, or not have the same density in different regions.

A common problem during injection molding of polymeric products is the formation of seals. Lines of seals are formed as a result of the presence in the mold of several gates or obstacles round which the molten polymeric material flows in the process of filling the mold cavity [4]. Most often, places of seals in products are characterized by low indicators of mechanical properties [5]. 
Given the labor intensity and high cost of manufacturing technological equipment, a responsible and careful approach is required to the process of designing the injection molds. In addition, it is necessary to take into consideration that shortcomings of the mold will inevitably lead to a large number of defective products during industrial production.

The possibility of control and targeted influence on the process of formation of seals will make it possible to improve design parameters of molds in order to ensure the required quality of finished products. Visualization of the process of filling a mold cavity with the molten polymer will enable determining the location of seals in a finished product. This will make it possible to improve and develop new designs of molds for the injection molding of parts of shoes with increased operational characteristics. In order to enable visualization of the process of filling a mold with a polymeric material, it is required to describe mathematically the motion of viscous fluid in the mold cavity.

\section{Literature review and problem statement}

The problem of the formation of seal lines arises with the advent of the injection molding process. The first important contribution to the solution of this problem was made by authors of papers [6,7] whose experimental results formed the basis for study [8]. Later in the 80's, authors of article [9] investigated the effect of rheological characteristics of the polymeric melt on the strength of seals.

Papers of modern scientists include both experimental research and the results of modeling the injection molding process.

Experimental research into the process of seal formation typically comes down to determining an influence of the characteristics of a material and the injection molding process parameters on strength of the formed seals.

Article [10] addresses optimization of the injection molding process in order to improve properties of the material in places where seals originate. However, a purely experimental approach does not make it possible to detect location of the seals in products for the case of molds with a complex geometry of the surface.

In paper [11], authors investigated the influence of technological parameters of the injection molding process on the strength and microstructure of polymeric material in the places of seals. The results of this study are related to a limited number of materials.

Study [12] focuses on the prediction of seal strength in parts made of amorphous thermoplastic materials. The strength of the product, however, is affected not only by the strength of the seal itself, but rather a seal orientation relative to the direction of load action.

Paper [13] proposed the introduction of additives in order to improve strength of the welding lines. In article [14], authors report results of a thorough study into the processes of formation of hot and cold seals. Nevertheless, technological preparation of the injection molding process and mold designing require more data than those obtained experimentally for particular cases.

As far as numerical simulation is concerned, it is possible to find a large number of studies whose authors employ software in order to predict influence of the properties of a material and the injection molding process parameters on seal lines formation in products.
The most popular software is the Autodesk, Inc.'s Moldflow Insight. For example, in paper [15], authors applied a method of numerical simulation for the prediction of seal formation process in the manufacture of small goods. Article [16] addresses exploring effect of the injection molding process parameters on the formation of seals. In study [17], numeric simulation of injection molding is used to design a mold in order to reduce defects in products. Similar tasks were solved in papers $[18,19]$. Other software programs that are less likely to be used are, for example, Moldex3D [20], Solidworks Plastics [21], Cadmould ${ }^{\circledR} 3 \mathrm{D}-\mathrm{F}$ [22], etc.

Authors of the indicated studies solve, to a greater extent, engineering and technological tasks. The scientific substantiation, however, necessitates development of a mathematical description of the process, the task that requires conducting a theoretical research.

\section{The aim and objectives of the study}

The aim of present work is the examination and mathematical description of the process of filling a mold cavity with a molten polymeric material, particularly, of the process of seal line formation in a product.

To achieve the set aim, the following tasks have been solved:

- to develop a mathematical model of the flow dynamics of viscous fluid with a free surface in order to visualize the process of filling a mold cavity with a melt of a polymeric material;

- to explore the impact of structural and technological parameters of injection molding equipment on the motion of a free surface front in the mold cavity;

- to conduct experimental studies in order to confirm adequacy of the mathematical model to actual processes.

\section{Polymeric materials used for fabricating shoes} by the method of injection molding

When manufacturing parts of the bottom of shoes, rubber compounds are widely used whose polymeric base is formed by butadiene-styrene, isoprene and polybutadiene rubbers [23].

The method of liquid formation is employed for making a polyurethane bottom of shoes [24, 25].

In addition to thermosetting plastics, when molding parts of the bottom of shoes, the following thermoplastic polymeric materials are applied: polyolefins, polyamides, capron, nylon, polystyrene, polyethylene, polypropylene.

Thermoplastic mixtures of different polymeric materials are also utilized: propylene, ethylene-propylene rubbers and polyolefins, ABS plastics [26, 27].

High operational qualities are characteristic of soles made of thermoelastic plastics: polyurethane, as well as divinyl styrene, isoprene styrene, divinyl and methyl styrene block copolymers [26].

Injection molding of rubber mixtures requires additional consumption of energy and time to perform viscous flow and vulcanization. Obtaining a reaction mixture of polyurethane requires specialized additional equipment. Thus, when choosing materials for the research, we selected thermoplastic materials. The latter include the widely-used plasticized mixtures based on polyvinyl chloride [23, 28, 29]. Given this, 
we have chosen the PVC-plasticizer OPLP-2 for experimental research.

\section{Results of numerical modeling of the process of filling a mold}

When building a mathematical model of flow dynamics of the melt of a polymeric material in the mold cavity, we adopted the following assumptions:

- the melt is a non-compressible fluid; lected;

- gravitational forces are so small that they can be neg-

- the flow is laminar;

- dissipative heating is disregarded;

- there is no slipping in the place of contact between a viscous fluid and the walls of the mold cavity.

The flow of a viscous fluid in the cavity of the mold is described by the Navier-Stokes equation for physical variables $u, v$ and pressure $p$. We shall consider the flat case only. Then the equations describing a laminar isothermal flow of the incompressible fluid, according to [30-32], will take the following form:

$$
\begin{aligned}
& \frac{\partial u}{\partial t}+u \cdot \frac{\partial u}{\partial x}+v \cdot \frac{\partial u}{\partial y}=-\frac{\partial \varphi}{\partial x}+v \cdot\left[\frac{\partial^{2} u}{\partial x^{2}}+\frac{\partial^{2} u}{\partial y^{2}}\right] \\
& \frac{\partial v}{\partial t}+u \cdot \frac{\partial v}{\partial x}+v \cdot \frac{\partial v}{\partial y}=-\frac{\partial \varphi}{\partial y}+v \cdot\left[\frac{\partial^{2} v}{\partial x^{2}}+\frac{\partial^{2} v}{\partial y^{2}}\right]
\end{aligned}
$$

where $u, v$ are the velocity vector projections onto the $x$ and $y$ axes; $\varphi$ is the ratio of pressure to density constant $\rho$ (hereinafter, pressure); $t$ is the time; $\mathrm{n}$ is the kinematic viscosity of the fluid, which is equal to the ratio of dynamic viscosity $\mu$ to density constant $\rho$.

These equations are supplemented by the condition of incompressibility [33, 34]:

$$
D=\operatorname{div} \bar{\vartheta}=\frac{\partial u}{\partial x}+\frac{\partial v}{\partial y}=0
$$

From equations (1) and (2), we shall obtain the Poisson's equation for pressure:

$$
\begin{aligned}
& \nabla^{2} \varphi=\frac{\partial^{2} \varphi}{\partial x^{2}}+\frac{\partial^{2} \varphi}{\partial y^{2}}= \\
& =-\frac{\partial D}{\partial t}-u \cdot \frac{\partial D}{\partial x}-v \cdot \frac{\partial D}{\partial y}-\frac{\partial^{2}\left(v^{2}\right)}{\partial y^{2}}+v \cdot \nabla^{2} D
\end{aligned}
$$

where $D$ is the divergence of velocity vector determined from relation (3).

Equations (1)-(3) are the main to determine a field of velocity and pressure. We shall add boundary conditions to them on the symmetry axis, at the border of the in-flow, on solid and free surfaces.

1. Boundary conditions on the axis of symmetry. In line with [35], we shall assume that on the axis of symmetry radial velocity $v$ and tangential stress $t$ are equal to zero (Fig. 1).

2. Boundary conditions near solid walls. According to [33], we shall accept that for the spots where a viscous fluid is adjacent to the solid stationary wall, velocity of the fluid tends to zero, that is, at the points of contact between a vis- cous fluid and a solid stationary wall, the normal and tangent components of velocity are equal to zero: $u=0, v=0$ (Fig. 1).

3. Boundary conditions for pressure near solid walls and on the axis of symmetry are unknown. They can be determined from motion equations (1) and (2) by substituting boundary velocities in them.

4. Boundary conditions on the border of the in-flow. According to [35], here we assign one of the components of velocity vector. Initial conditions of the problem are the values of velocity and pressure in the starting moment. It is required to assign initial position of the free surface at this point.

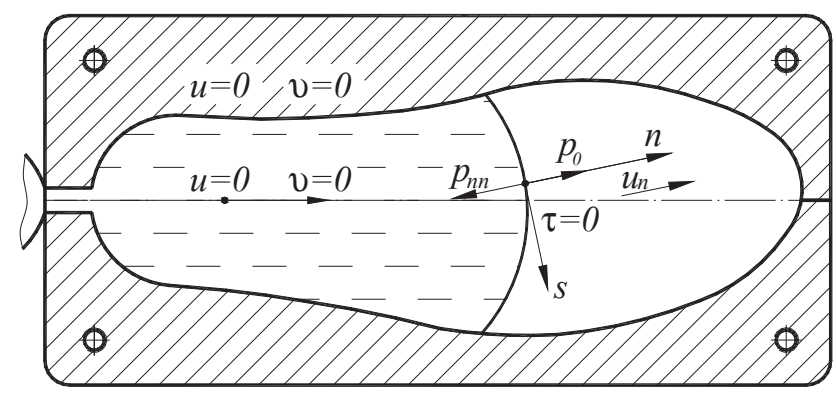

Fig. 1. Boundary conditions on the axis of symmetry, near solid walls, and on the free surface

Consider now boundary conditions on the free surface (Fig. 1) that borders a cavity, where pressure is of constant value $p_{0}$ [33]. The following conditions must be satisfied on the surface:

- a kinematic condition: the component of velocity that is normal to the free surface coincides with the displacement rate of the free surface front;

- a dynamic condition: stress vector $p_{n}$ for the regions, tangential to the free surface, is directed along the normal to these regions inside, and is equal in magnitude to $p_{0}$, that is, $p_{n n}=-p_{0}, p_{n s}=0$, where $s$ is any direction of the tangent to the surface at the considered point.

Pressure $p_{0}$ will hereafter be considered zero.

Write down the newly formulated boundary conditions on the free surface.

It follows from the kinematic condition that there are no tangent stresses on the free surface:

$$
v \cdot\left(\frac{\partial u_{n}}{\partial s}+\frac{\partial u_{s}}{\partial n}\right)=0
$$

We obtain from the dynamic condition:

$$
\varphi-2 v \cdot \frac{\partial u_{n}}{\partial n}=\varphi_{0}=0
$$

Conditions (5) and (6) belong to the local coordinate system $n, s$ ( $n$ - normal, $s$ tangent to the surface) relative to each point of the free surface. We shall record these equation in the Cartesian coordinates. To do this, we shall use formulas for transforming the coordinates [36, 37]:

$$
\begin{aligned}
& \left(\frac{\partial v}{\partial y}-\frac{\partial u}{\partial x}\right) \cdot \sin 2 \beta+\left(\frac{\partial u}{\partial y}+\frac{\partial v}{\partial x}\right) \cdot \cos 2 \beta=0 \\
& 2 \cdot\left(\frac{\partial u}{\partial x} \cdot \cos ^{2} \beta+\frac{\partial v}{\partial y} \cdot \sin ^{2} \beta\right)+\left(\frac{\partial v}{\partial x}+\frac{\partial u}{\partial y}\right) \cdot \sin 2 \beta=\frac{\varphi}{v},
\end{aligned}
$$


where $\beta$ is the angle between a positive direction of the $x$ axis and a positive direction of the normal to the free surface.

The present study examines slow flows of highly viscous fluids, which often occur during processing of polymers. In this case, viscous terms are several orders of magnitude larger than the inertial terms. Thus, according to the theory of a highly viscous fluid [21], equations (1) and (2) are written as follows:

$$
\begin{aligned}
& -\frac{\partial \varphi}{\partial x}+v \cdot\left[\frac{\partial^{2} u}{\partial x^{2}}+\frac{\partial^{2} u}{\partial y^{2}}\right]=0 \\
& -\frac{\partial \varphi}{\partial y}+v \cdot\left[\frac{\partial^{2} v}{\partial x^{2}}+\frac{\partial^{2} v}{\partial y^{2}}\right]=0 .
\end{aligned}
$$

All presented equations do not contain time. The entire process of a nonstationary flow is divided into a finite number of stationary problems, in other words, a hypothesis on quasi-stationarity is employed.

Equation (4) is the Poisson's equation for pressure $\varphi$. While satisfying the condition of non-compressibility, the above Poisson's equation becomes a Laplace equation for pressure $\varphi$ :

$$
\nabla^{2} \varphi=0
$$

By solving equations (9), (10) and (11) with the given boundary conditions, we shall determine, using a method of markers and cells (MAS), a velocity field and a pressure field.

In line with the MAC method, all differential equations and boundary conditions are recorded in the finite differences on a grid of fixed cells, which covers the region of flow of a viscous fluid. Time is also divided into a finite number of intervals. A system of particles-markers is applied to the volume and surface of the fluid, which are directly associated with the fluid. These particles can move along the Euler grid with a local fluid rate, indicating positions at a certain point in time in line with the Lagrange equation:

$$
\frac{d x}{d t}=u ; \quad \frac{d y}{d t}=v
$$

A typical cell is shown in Fig. 2. In each cell, one determines three independent variables $u, v, \varphi$, each of which is centered at separate points of the grid. Pressure, viscosity, if it is not constant, are assigned only in the center $i, j$ of each cell.

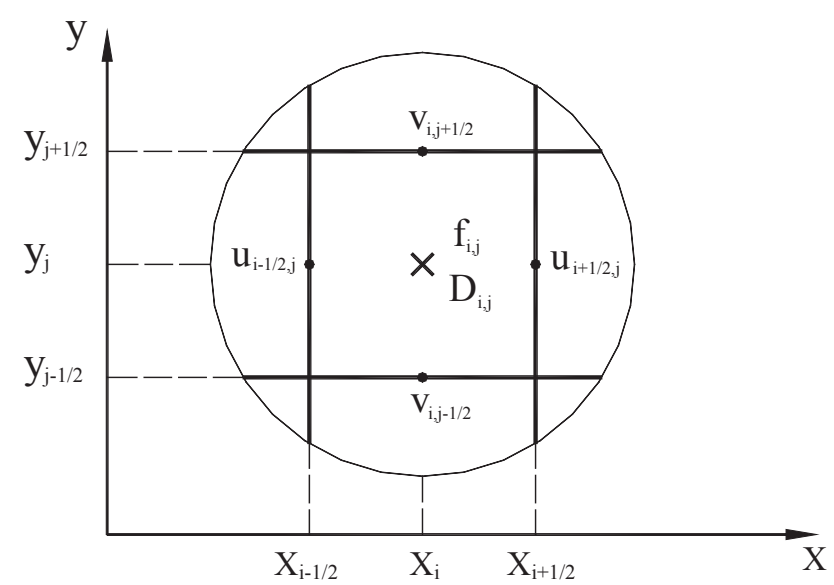

Fig. 2. Estimated cell
«Horizontal» velocity $u_{i+1 / 2, j}$ is determined only on the «vertical» borders of cells $\left(x_{i+1 / 2, j}, y_{j}\right)$ and, similarly, «vertical» velocity $\mathrm{u}_{i, j+1 / 2}$ is determined only on the «horizontal» borders of cells $\left(x_{i}, y_{j+1 / 2}\right)$. Hereafter, to avoid half-indices, velocities $u_{i+1 / 2, j}$ and $v_{i, j+1 / 2}$ will be denoted as $u_{i, j}$ and $v_{i, j}$, that is, we assign indexing of the velocities to the center, bearing in mind that they are centered at the midpoints of a cell sides.

Employing [38-40], we shall write differential motion equations (9) and (10) that describe a creeping flow in the finite-difference form, replacing differential operators with difference analogues:

$$
\begin{aligned}
& \frac{\varphi_{i, j}-\varphi_{i+1, j}}{h}+v \cdot\left[\frac{u_{i+1, j}-2 \cdot u_{i, j}+u_{i-1, j}}{h^{2}}+\right. \\
& \left.+\frac{u_{i, j+1}-2 \cdot u_{i, j}+u_{i, j-1}}{h^{2}}\right]=0 ; \\
& \frac{\varphi_{i, j}-\varphi_{i, j+1}}{h}+v \cdot\left[\frac{v_{i+1, j}-2 \cdot v_{i, j}+v_{i-1, j}}{h^{2}}+\right. \\
& \left.+\frac{v_{i, j+1}-2 \cdot v_{i, j}+v_{i, j-1}}{h^{2}}\right]=0 .
\end{aligned}
$$

The finite-difference analog of continuity equation will be written as follows:

$$
D_{i, j}=\frac{1}{h} \cdot\left(u_{i, j}-u_{i-1, j}+v_{i, j}-v_{i, j-1}\right)=0 .
$$

A pressure field in the creeping motion is described by equation (11) or in a difference form:

$$
\frac{\varphi_{i+1, j}-2 \cdot \varphi_{i, j}+\varphi_{i-1, j}}{h^{2}}+\frac{\varphi_{i, j+1}-2 \cdot \varphi_{i, j}+\varphi_{i, j-1}}{h^{2}}=0 .
$$

For the convenience of determining variables $u, v, \varphi$ in full cells by the iteration method, we shall use the following expressions:

$$
\begin{aligned}
& u_{i, j}=\frac{1}{4} \cdot\left[u_{i+1, j}+u_{i-1, j}+u_{i, j+1}+u_{i, j-1}-\frac{h}{v} \cdot\left(\varphi_{i+1, j}-\varphi_{i, j}\right)\right] ; \\
& v_{i, j}=\frac{1}{4} \cdot\left[v_{i+1, j}+v_{i-1, j}+v_{i, j+1}+v_{i, j-1}-\frac{h}{v} \cdot\left(\varphi_{i, j+1}-\varphi_{i, j}\right)\right] ; \\
& \varphi_{i, j}=\frac{1}{4} \cdot\left(\varphi_{i+1, j}+\varphi_{i-1, j}+\varphi_{i, j+1}+\varphi_{i, j-1}\right) .
\end{aligned}
$$

Expressions (17) form a complete system of linear algebraic equations for determining all the unknowns in different types of cells - boundary, full, and surface. In order to solve such systems, it is appropriate to use iterative solving methods that take into account a special form of such systems and are convenient for implementing using a computer [41-43].

We shall employ the iterative Liebmann method [41, 44, 45] involving consecutive relaxations:

$$
x^{k}=x^{k-1}+\omega \cdot\left(\mathbf{f}-\mathbf{A} \cdot x^{k-1}\right),
$$

where $\omega$ is the relaxation parameter, which takes values from 0 to 2 (at $\omega>1$, the process is called an «upper» relaxation; at $\omega<1$, it is called a «bottom» relaxation); $\mathbf{f}$ is the vector of free terms; $\mathbf{A}$ is the matrix of coefficients with the unknowns. 
It is difficult to analytically determine the optimal value of $\omega$. That is why, in this case, $\omega$ is determined using the numerical experiment. The value of $\omega$ is considered to be optimal if the magnitude of discrepancy is minimal at it.

The MAC method considers particles-markers that do not have weight and move at the local rate of a fluid. By observing them and mapping their position graphically, it is possible to receive a pattern of fluid distribution in space.

The position of each particle $x_{m}, y_{m}$ is determined using a numerical integration from some initial position $x_{m}^{0}, y_{m}^{0}$, which the particle took in the moment of time $t=0$ :

$$
x_{m}=x_{m}^{0}+\int_{0}^{t} u_{m} \cdot \mathrm{d} t ; \quad y_{m}=y_{m}^{0}+\int_{0}^{t} v_{m} \cdot \mathrm{d} t,
$$

where $u_{m}, v_{m}$ are the components of velocity vector of the marker at the point where it is at the given moment of time.

Assuming that over a one-time step, which is a very small amount of time, the markers' velocities are constant, it is possible to write:

$$
x_{m}^{n}=x_{m}^{n-1}+u_{m} \cdot \Delta t ; \quad y_{m}^{n}=y_{m}^{n-1}+v_{m} \cdot \Delta t,
$$

where $x_{m}^{n}, y_{m}^{n}$ are the current coordinates of the marker; $x_{m}^{n-1}$, $y_{m}^{n-1}$ are the marker's coordinates before displacement.

Markers' velocity is determined using a linear interpolation.

$$
u_{m}=\frac{s_{1} \cdot u_{i-1, j+1}+s_{2} \cdot u_{i, j+1}+s_{3} \cdot u_{i-1, j}+s_{4} \cdot u_{i, j}}{h^{2}},
$$

where $s_{1}, s_{2}, s_{3}, s_{4}$ are the rectangles' areas that are determined from the position of marker in the cell (Fig. 3).

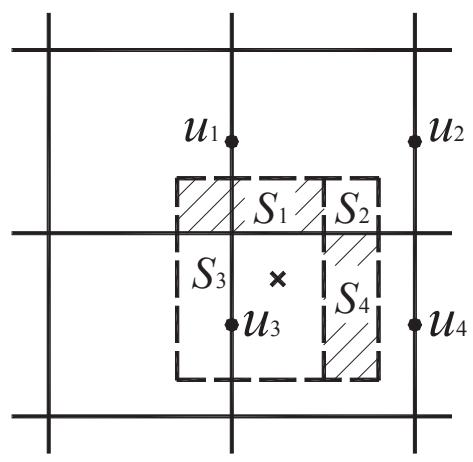

Fig. 3. Scheme for determining areas of rectangles

Interpolation formulae differ from each other depending on the position of a marker in the cell.

Similar interpolation formulae will be obtained when determining a vertical component of the marker's velocity vector.

\section{Experimental research into the mold filling process}

In order to further use results of analytical research, a practical test is required. To determine adequacy of the mathematical model to the actual processes, we conducted experimental research using mathematical methods of planning and analysis of the experiment.

We utilized the PVC-plasticizer OPLP-2 during experiments; its characteristics are given in Table 1 [5]:
Table 1

Characteristics of the examined material

\begin{tabular}{|c|c|c|c|}
\hline Material & $\begin{array}{c}\text { Processing tem- } \\
\text { perature, }{ }^{\circ} \mathrm{C}\end{array}$ & $\begin{array}{c}\text { Injection molding } \\
\text { pressure, } \mathrm{MPa}\end{array}$ & $\begin{array}{c}\text { Hardening tem- } \\
\text { perature, }{ }^{\circ} \mathrm{C}\end{array}$ \\
\hline PVC & $145-180$ & $40-100$ & 87 \\
\hline
\end{tabular}

To determine a position of the free surface front and its motion rate, we assembled an experimental setup on a thermoplastic automatic machine at Khmelnytsky shoe factory (Ukraine), which allowed us to come maximally close to the actual conditions that take place in the footwear production.

In order to conduct research, we specifically designed and manufactured an experimental mold whose design makes it possible to visually observe the motion of the polymeric melt.

The research was carried out on the experimental setup, a schematic of which is shown in Fig. 4.

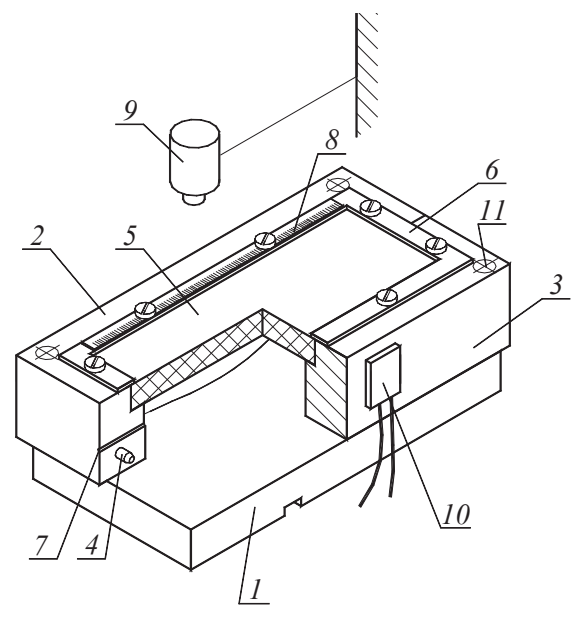

Fig. 4. Schematic of the experimental setup for determining a position and rate of the free surface of a polymeric melt:

1 - liner; 2, 3 - half matrices; 4 - centrifugal pins;

5 - glass plate; 6 - pressure plate; 7 - gate channel; 8 - measuring liner; 9 - video camera; 10 - temperature sensor; 11 - openings for mounting the mold carriers (4 pieces)

The installation for conducting experimental studies operates in the following way.

The clamping device of the thermoplastic automatic machine holds, via a groove, liner 1 . Half matrices 2 and 3 are attached by bolts to the mold carriers, which enable an automatic connection and disconnection of half matrices before filling and after product formation, respectively. Centering the half matrices implies using conical pins 4. By using a manual control unit over a thermoplastic automatic machine, liner 1 , half matrices 2 and 3 are pressed to each other. Next, glass plate 5 is put atop, which is rigidly fixed by pressure plate 6 . Thus a mold cavity is formed, to which, through gate channel 7 , by using the thermoplastic automatic machine, model B2S/14E, a melt polymer is fed. The process of motion of the molten mass is captured by video camera 9 , which is stationary fixed over glass plate 5 . To determine a position of the melt of a polymeric material at different moments of time, measuring liner 8 is fixed on the pressure plate, while one of the two mold carriers holds an electronic liquid crystal clock (not shown). 
We shall derive a function of dependence of motion rate of the free surface of a polymeric melt on the height and width of the mold cavity:

$$
\begin{aligned}
& v=0.03-1.5 \cdot H+1.84 \cdot B+ \\
& +40.82 \cdot H \cdot B-55,10 \cdot H^{2}-22.45 \cdot B^{2} .
\end{aligned}
$$

The obtained equations allow us to describe the process of filling a mold with a polymeric material taking into account two factors - the height and width of the mold cavity.

Fig. 5, 6 show graphic dependences of the magnitude of motion rate of the free surface of a polymeric melt on the height and width of the mold cavity. The charts shown were obtained as a result of experimental and numerical studies into the process of filling a mold with a polymeric material.

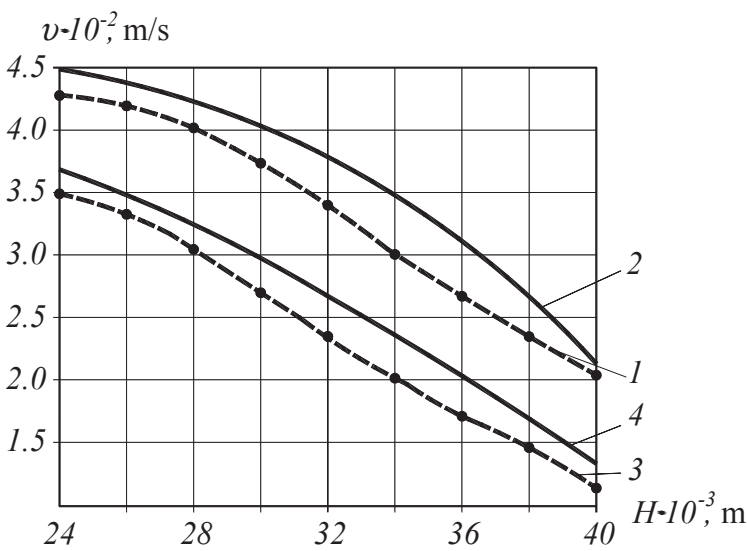

Fig. 5. Dependences of rate $v$ of the motion of the free surface front of a polymeric melt on height $H$ of the mold cavity: 1, 2- analytical and experimental, with a width of mold cavity $B=0.07 \mathrm{~m} ; 3,4-$ analytical and experimental at $B=0.083 \mathrm{~m}$

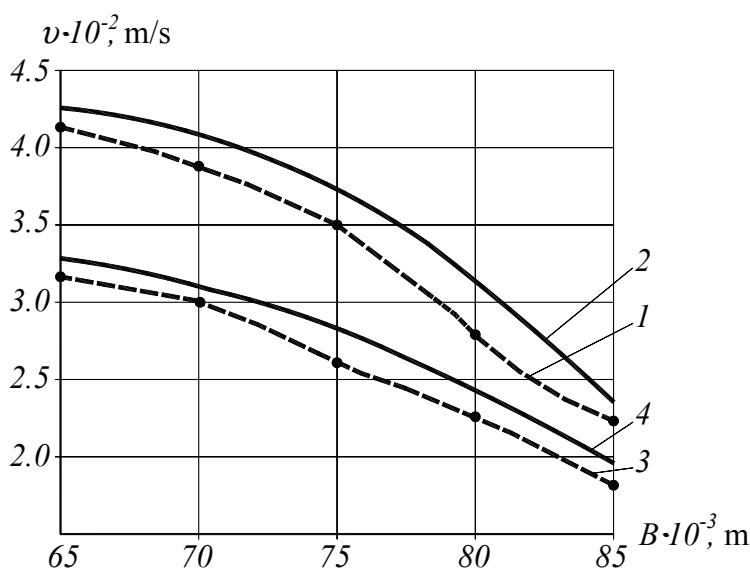

Fig. 6. Dependences of rate $v$ of the motion of the free surface front of a polymeric melt on width $B$ of the mold cavity: 1, 2- analytical and experimental, with a height of mold cavity $H=0.028 \mathrm{~m} ; 3,4-$ analytical and experimental at $H=0.035 \mathrm{~m}$

The charts shown (Fig. 5, 6) demonstrate that the numerical model and the obtained regressive dependences are in satisfactory agreement (a relative deviation of the experimental values from the theoretical values does not exceed $12 \%$ ). This fact confirms the appropriateness of using a mathematical model to study processes that occur when filling a mold with molten polymeric material.

\section{Discussion of results of research into the process of seal line formation when filling a mold}

As noted earlier, in the places of seal formation a product has low operational properties, which reduces reliability of the product. If it is impossible to avoid seal formation in the process of injection molding, then it is necessary to ensure that the seals are absent in those regions of the product, which accept maximal operating loads. The mathematical model obtained in the present work makes it possible to visually observe the process of seal formation and to predict quality of the product. By applying the proposed method, it is possible to change position of the seals by choosing design parameters of the mold, in particular, the dimensions and location of the intake openings.

Fig. 7, $a$ shows design of the actual mold that was used in the injection molding of soles for a shoe workpiece with a textile upper, and for modeling the process of filling a mold. It is possible to see that the line of seal in the finished product is located in the beam zone, which accepts maximal operational loads as a result of stretching and compressing this section at each step. When using such shoes, the sole was cracking in the beam zone.

The studies conducted have allowed us to propose a design of the mold, which made it possible to obtain products with improved performance properties. A change in the location of the intake openings in a mold shifts the lines of seals to the less loaded section (Fig. 7, $b$ ).
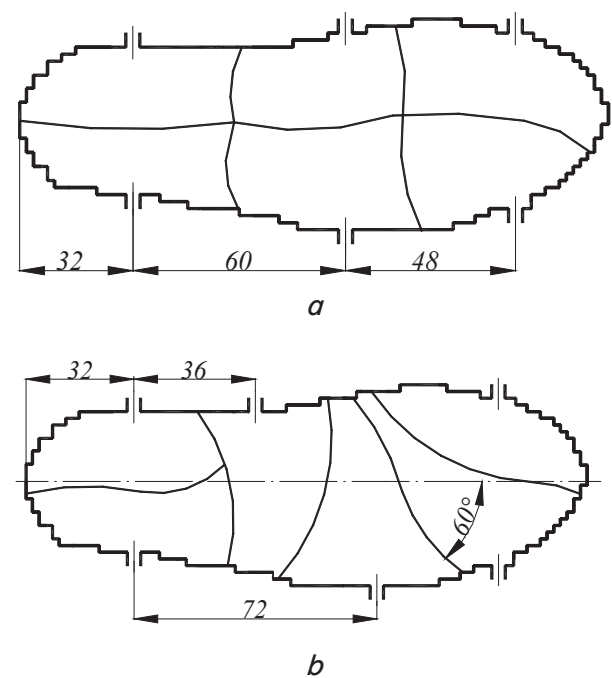

Fig. 7. Position of the lines of seals in the finished product obtained: $a-$ using a prototype mold; $b$ - using the proposed mold

The use of MAC method enables prediction of the formation of lines of seals when a molten polymer flows round the obstacles. It is also possible to devise recommendations for choosing optimal technological parameters for the process to better fill the mold during injection molding of large-size products through one intake opening. This makes it possible to avoid formation of the seals in a product, as well as improve its strength characteristics. 


\section{Conclusions}

1. A mathematical model was developed of the dynamics of non-isothermal flow of a viscous fluid in the mold cavity, which makes it possible to visualize the process of filling a mold with a molten polymer. The model includes the Navier-Stokes equations, the equation of continuity and the Laplace equations. As a result of solving the specified system of equations, we determined rate components of a two-dimensional flow, as well as pressure of the melt in the process of filling a mold. This enables observation of the process of seal formation and allows determining location of the seals in the finished product.

2. We investigated the process of seal formation, which revealed that the position of the lines of seal depends on the design parameters of gate equipment and practically does not depend on the technological factors of the injection molding process.

3. We designed an experimental installation for the visual observation and video recording of the process of filling a mold under conditions of shoe production. The results of analytical studies are confirmed: a maximal deviation from the experimental values does not exceed $12 \%$. We obtained experimentally the functional dependences of the operational properties of parts of the shoe bottom on the orientation of seals. It was established that an increase in the strength of the molded polymeric parts could be achieved by arranging the lines of seal at minimal angle to the direction of action of destructive load.

The use of a mathematical model of the dynamics of non-isothermal flow of a viscous fluid with free surface makes it possible to determine the rate, position of the melt front at different stages of the process of filling a mold. This enable prediction of the location and shape of the seals that occur in the finished products as a result of contact between the surfaces of melt fronts.

The studies conducted ensure a possibility to significantly reduce the cost of designing technological equipment and to avoid manufacturing low-quality products caused by the imperfection of molds or by the wrong choice of technological parameters of the injection molding process.

\section{References}

1. Ciofu, C. Injection and micro injection of polymeric plastics materials: a review [Text] / C. Ciofu, D. T. Mindru // International Journal of Modern Manufacturing Technologies. - 2013. - Vol. V, Issue 1. - P. 49-68.

2. Siva Kishore Babu, K. Forming and shaping of plastic materials by using CNC machines [Text] / K. Siva Kishore Babu, B. Koteswararao, P. S. Prema Kumar // International journal of advancement in engineering technology, management and applied science. 2016. - Vol. 03, Issue 09. - P. 74-89.

3. Ozcelik, B. Optimization of injection parameters for mechanical properties of specimens with weld line of polypropylene using Taguchi method [Text] / B. Ozcelik // International Communications in Heat and Mass Transfer. - 2011. doi: 10.1016/j.icheatmasstransfer.2011.04.025

4. Sun, X. J. Weld Line Factors for Thermoplastics [Text] / X. J. Sun, P. Tibbenham, J. Zhou, D. Zeng, S. Huang, L. Lu, X. Su // SAE Technical Paper Series. - 2017. doi: 10.4271/2017-01-0481

5. Wu, C.-H. Effects of geometry and injection-molding parameters on weld-line strength [Text] / C.-H. Wu, W.-J. Liang // Polymer Engineering \& Science. - 2005. - Vol. 45, Issue 7. - P. 1021-1030. doi: 10.1002/pen.20369

6. Gilmore, G. D. Role of pressure, temperature and time in the injection molding process [Text] / G. D. Gilmore, R. S. Spencer // Modern Plastics. - 1950. - Vol. 37, Issue 8. - P. 143-151.

7. Spencer, R. S. Some flow phenomena in the injection molding of polystyrene [Text] / R. S. Spencer, G. D. Gilmore // Journal of Colloid Science. - 1951. - Vol. 6, Issue 2. - P. 118-132. doi: 10.1016/0095-8522(51)90032-3

8. Beyer, C. E. Rheology in Molding [Text] / C. E. Beyer, R. S. Spencer // Rheology. - 1960. - P. 505-551. doi: 10.1016/b978-0-12395696-5.50019-8

9. Pisipati, R. Correlation of Non-Linear Rheological Properties of Polymer Melts With Weld-Line Strength [Text] / R. Pisipati, D. G. Baird // Polymer Processing and Properties. - 1984. - P. 215-228. doi: 10.1007/978-1-4613-2781-3_21

10. Chang, T. C. Optimization of weld line quality in injection molding using an experimental design approach [Text] / T. C. Chang, E. Faison // Journal of Injection Molding Technology. - 1999. - Vol. 2. - P. 61-66.

11. Turng, L.-S. Effect of process conditions on the weld-line strength and microstructure of microcellular injection molded parts [Text] / L.-S. Turng, H. Kharbas // Polymer Engineering \& Science. - 2003. - Vol. 43, Issue 1. - P. 157-168. doi: 10.1002/pen.10013

12. Onken, J. Prediction of weld line strength in injection-moulded parts made of unreinforced amorphous thermoplastics [Text] / J. Onken, C. Hopmann // International Polymer Science and Technology. - 2016. - Vol. 43, Issue 11. - P. T/1-T/8.

13. Mielewski, D. F. Weld line morphology of injection molded polypropylene [Text] / D. F. Mielewski, D. R. Bauer, P. J. Schmitz, H. Van Oene // Polymer Engineering \& Science. - 1998. - Vol. 38, Issue 12. - P. 2020-2028. doi: 10.1002/pen.10371

14. Xie, L. Investigation on correlation between cold/hot weld line mechanical properties and micro injection molding processing parameters [Text] / L. Xie, D. Zhu, G. Ziegmann, L. Steuernagel // NSTI-Nanotech 2010. - 2010. - Vol. 2. - P. 292-295.

15. Xie, L. Numerical simulation method for weld line development in micro injection molding process [Text] / L. Xie, G. Ziegmann, B. Jiang // Journal of Central South University of Technology - 2009. - Vol. 16, Issue 5. - P. 774-780. doi: 10.1007/s11771-009-0129-9

16. Dzulkipli, A. A. Study of the Effects of Injection Molding Parameter on Weld Line Formation [Text] / A. A. Dzulkipli, M. Azuddin // Procedia Engineering. - 2017. - Vol. 184. - P. 663-672. doi: 10.1016/j.proeng.2017.04.135

17. Shinde, M. P. P. Design of plastic injection mold using simulation technique for minimizing defect [Text] / M. P. P. Shinde, S. S. Patil, S. S. Awati, A. S. Patil // International Research Journal of Engineering and Technology. - 2016. - Vol. 03, Issue 10. - P. $1004-1010$. 
18. Deng, Y.-M. Injection Molding Optimization for Minimizing the Defects of Weld Lines [Text] / Y.-M. Deng, D. Zheng, B.-S. Sun, H.-D. Zhong // Polymer-Plastics Technology and Engineering. - 2008. - Vol. 47, Issue 9. - P. 943-952. doi: 10.1080/ 03602550802274555

19. Perfilova, V. Yu. Proektirovanie press-form s pomoshch'yu noveyshih programmnyh sredstv s privlecheniem sistemy modelirovaniya processa lit'ya plastmass Autodesk Simulation Moldflow [Text] / V. Yu. Perfilova // Kompleksnye problemy razvitiya nauki, obrazovaniya i ekonomiki regiona. - 2015. - Issue 2. - P. 79-88.

20. Mahov, S. I. Proektirovanie lit'evyh form s ispol'zovaniem sistem inzhenernogo analiza [Text] / S. I. Mahov, I. S. Novikov, M. V. Kangin // Tekhnicheskie nauki - ot teorii k praktike. - 2013. - Issue 17-1. - P. 60-68.

21. Kopeliovich, D. I. Analiz vozmozhnostey modulya Solidworks Plastics dlya proektirovaniya press-form [Text] / D. I. Kopeliovich, S. A. Kadushkina // Perspektivy razvitiya informacionnyh tekhnologiy. - 2016. - Issue 30. - P. 38-42.

22. Tan, Y. Evaluation of Weld Line Strength in Low Density Polyethylene Specimens by Optical Microscopy and Simulation [Text] / Y. Tan, Z. Mohamad Ariff, G. L. Khoo // Journal of Engineering Science. - 2017. - Vol. 13. - P. 53-62. doi: 10.21315/jes2017.13.4

23. Al'tzicer, V. S. Proizvodstvo obuvi iz polimernyh materialov [Text] / V. S. Al'tzicer, V. N. Krasovskiy, V. D. Meerson; V. A. Berestnev (Ed.). - Leningrad: Himiya, 1987. - 231 p.

24. Veynberg, I. A. Izgotovlenie niza obuvi metodom lit'ya [Text] / I. A. Veynberg // Kozhevenno-obuvnaya promyshlennost'. - 1971. Issue 7. - P. 24-25.

25. Shvarc, A. S. Sovremennye materialy i ih primenenie v obuvnom proizvodstve [Text] / A. S. Shvarc, E. F. Kondrat'kov. - Moscow: Legkaya industriya, 1978. - $224 \mathrm{p}$.

26. Nikitina, L. L. Sovremennye polimernye materialy, primenyaemye dlya niza obuvi [Text] / L. L. Nikitina, G. I. Garipova, O. E. Gavrilova // Vestnik Kazanskogo tekhnologicheskogo universiteta. - 2011. - Issue 6. - P. 150-154.

27. Musoev, S. S. Poliolefinovye termoplastichnye elastomery - materialy dlya niza obuvi [Text] / S. S. Musoev, A. A. Karpuhin, G. P. Andrianova // Kozhevenno-obuvnaya promyshlennost'. - 1992. - Issue 6. - P. 32-34.

28. Brudnyy, R. N. Proizvodstvo obuvi iz PVH metodom lit'ya pod davleniem [Text] / R. N. Brudnyy, S. N. Gromov. - Leningrad: Himiya, 1976. -87 p.

29. Emec, L. V. Polimery v kozhevenno-obuvnoy promyshlennosti [Text] / L. V. Emec, V. M. Vaynberg. - Leningrad: LIGLP, 1985. - 52 p.

30. Astarita, Dzh. Osnovy gidromekhaniki nen'yutonovskih zhidkostey [Text] / Dzh. Astarita, Dzh. Maruchchi. - Moscow: Mir, 1981. -310 p.

31. Deyli, Dzh. Mekhanika zhidkosti [Text] / Dzh. Deyli, E. Harleman. - Moscow: Energiya, 1971. - 480 p.

32. Temam, R. Uravnenie Nav'e-Stoksa. Teoriya i chislennyy analiz [Text] / R. Temam. - Moscow: Mir, 1981. 408 p.

33. Kochin, N. E. Teoreticheskaya gidromekhanika. Ch. 2 [Text] / N. E. Kochin, I. A. Kibel', N. V. Roze. - Moscow: Fizmatgiz, 1963. $-728 \mathrm{p}$.

34. Loycyanskiy, L. G. Mekhanika zhidkosti i gaza [Text] / L. G. Loycyanskiy. - 5-e izd. - Moscow: Nauka, 1978. - 736 p.

35. Berezin, I. K. Metody rascheta techeniy so svobodnymi granicami [Text] / I. K. Berezin, G. V. Levina // Reologicheskie svoystva polimernyh sistem. - Sverdlovsk: UNC AN SSSR, 1979. - P. 20-28.

36. Vygodskiy, M. Ya. Spravochnik po vysshey matematike [Text] / M. Ya. Vygodskiy. - Moscow: Nauka, 1982. - 872 p.

37. Korn, G. Spravochnik po matematike dlya nauchnyh rabotnikov [Text] / G. Korn, T. Korn. - Moscow: Nauka, 1977. - 720 p.

38. Samarskiy, A. A. Vvedenie v chislennye metody [Text]: ucheb. pos. / A. A. Samarskiy. - 2 e izd. - Moscow: Nauka, 1987. - 288 p.

39. Samarskiy, A. A. Metody resheniy setochnyh uravneniy [Text] / A. A. Samarskiy, E. S. Nikolaev. - Moscow: Mir, 1981. - 626 p.

40. Samarskiy, A. A. Teoriya raznostnyh skhem [Text] / A. A. Samarskiy. - Moscow: Nauka, 1983. - 616 p.

41. Vazov, V. Raznostnye metody resheniya differencial'nyh uravneniy v chastnyh proizvodnyh [Text] / V. Vazov, Dzh. Forsayt. - Moscow: Izd-vo inostr. lit., 1963. - 487 p.

42. Sharkovskiy, A. N. Raznostnye uravneniya i ih prilozheniya [Text] / A. N. Sharkovskiy. - Kyiv: Naukova dumka, 1986. -280 p.

43. Yacenko, V. S. Metod drobnyh shagov [Text] / V. S. Yacenko. - Kyiv: Vishcha shkola, 1983. - 134 p.

44. Demidovich, B. P. Chislennye metody analiza. Priblizhenie funkciy, differencial'noe i integral'nye ischisleniya [Text] / B. P. Demidovich, K. G. Maron. - 3-e izd. - Moscow: Nauka, 1977. - 368 p.

45. Heygeman, L. Prikladnye iteracionnye metody [Text] / L. Heygeman, D. Yang. - Moscow: Mir, 1986. - 446 p.

46. Lapshin, V. V. Osnovy pererabotki termoplastov lit'em pod davleniem [Text] / V. V. Lapshin. - Moscow: Himiya, 1974. - 270 p. 